\title{
Surgical Experience of Primary Hyperparathyroidism: Analysis of Postoperative Outcomes
}

\author{
Hee Jeong Kang, Hee Ryung Kim, Ha Na Lee, Chang Myeon Song, \\ Yong Bae Ji, and Kyung Tae (iD \\ Department of Otorhinolaryngology-Head and Neck Surgery, Hanyang University College of Medicine, Seoul, Korea
}

\author{
원발성 부갑상선 기능 항진증의 수술: 술후 결과 분석 \\ 강희정 · 김희령 · 이하나 · 송창면 · 지용배 · 태 경 \\ 한양대학교 의과대학 이비인후-두경부외과학교실
}

\author{
Received February 19, 2020 \\ Revised May 13, 2020 \\ Accepted May 14, 2020 \\ Address for correspondence \\ Kyung Tae, MD, PhD \\ Department of Otolaryngology- \\ Head and Neck Surgery, \\ College of Medicine, \\ Hanyang University, \\ 222 Wangsimni-ro, Seongdong-gu, \\ Seoul 04763, Korea \\ Tel $+82-2-2290-8585$ \\ Fax $+82-2-2293-3335$ \\ E-mail kytae@hanyang.ac.kr
}

Background and Objectives The standard surgical procedure for primary hyperparathyroidism is the bilateral exploration. However, the unilateral exploration and direct focused parathyroidectomy have been performed to reduce surgical morbidity. The purpose of this study was to report the surgical outcomes and efficacy of the bilateral exploration, unilateral exploration, and direct focused approaches for primary hyperparathyroidism.

Subjects and Method We retrospectively analyzed the surgical outcomes of 87 patients with primary hyperparathyroidism from January 2007 to December 2017. We compared the operative time, complication and recurrence rate between the three operative methods.

Results The most common histopathology was parathyroid adenoma, which was found in 73 cases $(83.9 \%)$, followed by hyperplasia. In terms of complications, there were two cases of transient vocal cord palsy, one case of hematoma, one case of hypocalcemia and one case of hungry bone syndrome. Recurrence occurred in two (2.3\%) out of 87 cases. There was no significant difference in the recurrence rate between the three surgical approaches.

Conclusion The success rate of surgery for primary hyperparathyroidism is high. Direct focused parathyroidectomy may be a good option for parathyroid adenoma if the localization tests localize the lesion. The bilateral exploration is effective for parathyroid hyperplasia.

Korean J Otorhinolaryngol-Head Neck Surg 2021;64(4):252-7

\section{서 론}

최근 건강 검진 활성화로 인한 혈액 생화학 검사의 증가로 과거에 비하여 부갑상선 기능 항진증의 진단율이 높아지는 추세이며 조기 발견이 쉬워졌다. 원발성 부갑상선 기능 항진 증은 특별한 생리적 자극이 없는 상태에서 혈중 부갑상선 호 르몬이 과도하게 분비되는 질환으로, 결과적으로 혈중 칼숨

This is an Open Access article distributed under the terms of the Creative Commons Attribution Non-Commercial License (https://creativecommons.org/licenses/by-nc/4.0) which permits unrestricted non-commercial use, distribution, and reproduction in any medium, provided the original work is properly cited.
농도의 상승을 초래한다. 발생 빈도는 50 세 이상에서 1000명 당 4 6명이며, 남녀 비는 약 1:2에서 1:4로 특히 65세 이상의 폐경기 여성에서 빈도가 높다. 증상 없이 혈액검사나 영상검 사를 통하여 우연히 발견되는 경우가 가장 많으며 혈중 칼슘 농도의 상승으로 인하여 요로결석, 골 관련 질환, 심혈관계 질환, 소화기계 증상 등을 동반한다.,2)

원발성 부갑상선 기능 항진증의 가장 흔한 원인은 부갑상 선 선종으로 약 80 85\%를 차지하며, 그 외에 부갑상선 증식 증이 약 12 15\%, 다발성 부갑상선 선종이 1 2\%를 차지하며, 드물게 약 $1 \%$ 미만에서 부갑상선암종에 의해 야기된다. ${ }^{3)}$ 부 
갑상선 선종은 주로 하부갑상선에서 발생하며 크기는 다양 하다. 대부분 1 개의 부갑상선에서 발생하며 2 개 이상에서 생 기는 다발성 부갑상선 선종은 드물다. 부갑상선 증식증은 다 발성으로 2개 이상의 부갑상선을 침범하는데 대부분은 4 개 의 부갑상선을 모두 침범한다. 부갑상선암의 발생 빈도는 2 백 만 명당 1명 정도로 매우 드물며 남녀 비는 비슷하나 남자가 약간 많고, 일반적으로 혈중 칼슘 수치가 $14 \mathrm{mg} / \mathrm{dL}$ 이상으로 매우 높으며, 부갑상선 호르몬도 정상에 비해 5배 이상(300 $\mathrm{pg} / \mathrm{mL}$ 이상)으로 높은 경우가 많다. ${ }^{4)}$

원발성 부갑상선 기능 항진증의 주 치료법은 수술이며, 양 측 부갑상선을 모두 확인하고 병변을 완전히 제거하는 양측 경부탐색법(bilateral exploration)이 가장 정확한 표준적 수술 방법으로, 수술의 성공률은 95\% 이상이다. ${ }^{2)}$ 다른 술식으로 양측 부갑상선 탐색법의 침습성을 줄이기 위하여 일측 경부 만을 박리하여 2개의 부갑상선을 탐색하는 일측 경부탐색법 (unilateral exploration)이 제안되었으며, 최근에는 부갑상선 병변의 위치를 찾는 술전 국소화 진단법의 발달과 더불어 수 술의 침습성을 더욱 줄이고자 병변이 있는 부갑상선만을 제 거하는 최소 침습법(minimally invasive parathyroidectomy, direct focused parathyroidectomy)이 시도 되고 있다.")

원발성 부갑상선 기능 항진증의 여러 수술법은 서로 다른 장단점이 있고 수술법의 선택에 있어서 아직 논란이 있다. 이 에 저자들은 원발성 부갑상선 기능 항진증으로 수술한 환자 에서 술후 결과를 분석하고 각 술식의 장단점을 비교하여 추후 수술적 치료에 도움을 얻고자 본 연구를 시행하였다.

\section{대상 및 방법}

2007년 1월 2017년 12월까지 원발성 부갑상선 기능 항진 증으로 한양대학교병원 이비인후과에서 부갑상선 절제술을
받은 환자 87명을 대상으로 후향적 연구를 시행하였다. 본 연구는 한양대학교 구리병원 임상시험 심사위원회(Institutional Review Board)의 승인을 받았다(IRB file number 2018-07-034). 대상 환자의 임상 증상, 술전 영상검사 방법, 수술 방법, 수술 시간, 조직병리학적 결과, 수술 전후 혈중 칼 슘농도 및 부갑상선호르몬 농도(intact parathyroid hormone, $\mathrm{iPTH}$, 술후 합병증과 재발 유무 등을 조사하였다.

술전 영상검사로는 경부 초음파(ultrasonography), 경부 전 산화단층촬영(CT), 부갑상선 스캔 ${ }^{99 m} \mathrm{Tc}-$ sestamibi scan)을 시행하였다. 수술 방법은 수술 범위에 따라 양측 경부탐색법, 일측 경부탐색법, 최소 침습법으로 분류하였다. 저자들이 시 행한 최소 침습법은 direct focused parathyroidectomy로 병 변이 있는 한 개의 부갑상선만을 확인하고 절제하는 방법이 다. 수술 전 병소의 위치가 확인된 부위에 약 $2 \sim 3 \mathrm{~cm}$ 정도의 절개선을 만들고 흥쇄유돌근과 띠근육(strap muscle) 사이로 접근하여 갑상선을 전방 내측으로 견인한 후 병변이 있는 부 갑상선을 확인하고 제거하였다(Fig. 1).

술전 영상 검사에서 단일 병변의 위치가 확인된 경우는 direct focused parathyroidectomy나 일측 경부탐색법을 시행 하였으며, 술전 영상 검사에서 병변의 위치가 확인되지 않거 나 다발성 병변이 의심되는 경우 양측 경부탐색법을 시행하 였다. 갑상선 병변으로 갑상선 수술을 같이 시행한 경우는 갑 상선 병변의 위치에 따라 일측 또는 양측 경부탐색법을 시행 하였다.

통계 분석은 그룹 간의 차이를 분석하기 위하여 범주형 자 료의 비교는 chi-square 검정을, 연속형 자료의 비교는 Kruskall Wallis 검정을 이용하였다. 통계 분석은 컴퓨터 통계 분 석 프로그램(SPSS version 20.0; IBM Corp., Armonk, NY, $\mathrm{USA}$ )을 이용하였으며, 통계학적 유의수준 $95 \%$ 이상 $(p$ value $<0.05)$ 으로 하였다.
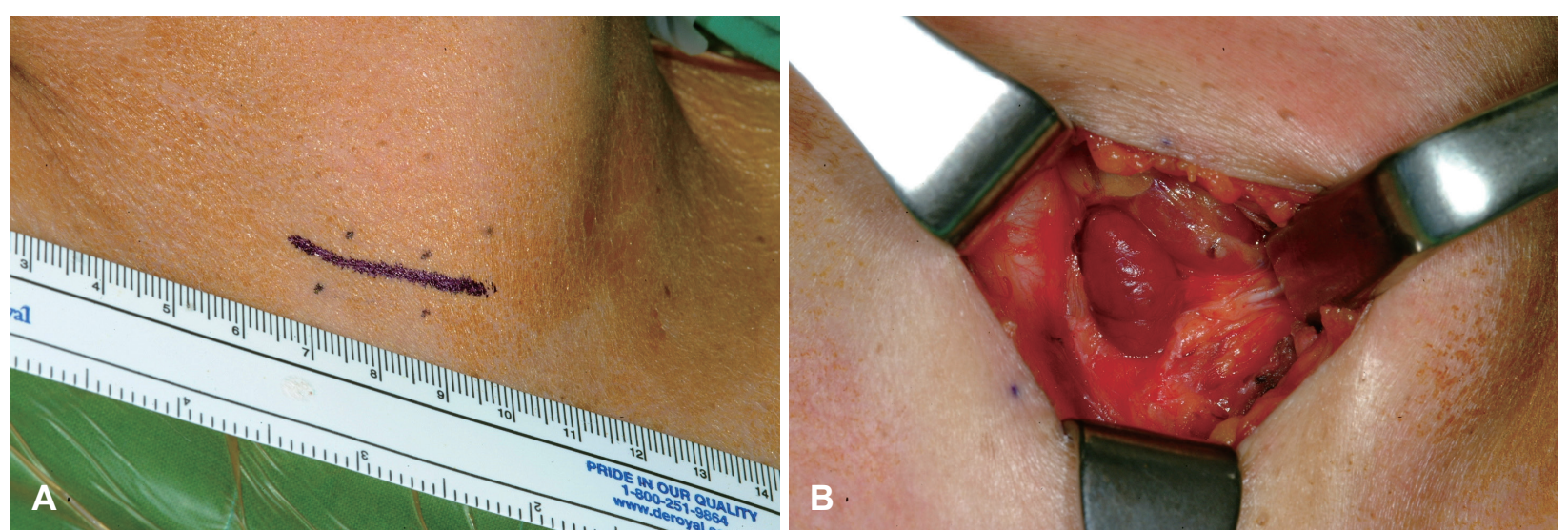

Fig. 1. The operative procedure of direct focused parathyroidectomy. An about $2-3 \mathrm{~cm}$ sized incision is made (A). Parathyroid adenoma is identified between the sternocleidomastoid muscle and strap muscle (B). 


\section{결 과}

임상 양상 및 병리 소견

대상자 87명 중 남자가 24명(27.6\%), 여자가 63명(72.4\%)이 며 환자의 연령분포는 17세부터 83세로 평균 $58.7 \pm 15.6$ 세였다.

호소하는 증상으로는 무증상이 61명(70.1\%), 골통증이 12명 (13.8\%), 요석이 5명(5.7\%), 피로와 전신 쇠약감이 4명(4.6\%), 경부 종물이 2명(2.3\%), 소화기계 증상이 2명(2.3\%), 근육 경 련이 1 명 $(1.1 \%)$ 이었다.

술전 측정한 평균 혈중 칼슘은 $11.11 \pm 1.49 \mathrm{mg} / \mathrm{dL}$ 였으며 평균 혈중 $\mathrm{iPTH}$ 는 $220.79 \pm 270.64 \mathrm{pg} / \mathrm{mL}$ 였다. 술후 1 주일 이내 측정한 혈중 칼슘은 $8.90 \pm 0.90 \mathrm{mg} / \mathrm{dL}$, 혈중 $\mathrm{iPTH}$ 는 $27.60 \pm 27.59 \mathrm{pg} / \mathrm{mL}$ 였으며 술후 6 개월에 측정한 혈중 칼슘 농도는 $9.27 \pm 0.65 \mathrm{mg} / \mathrm{dL}$, 혈중 iPTH는 $52.18 \pm 38.22 \mathrm{pg} / \mathrm{mL}$ 로 대부분의 환자에서 정상 범위로 돌아왔다.

조직병리검사 결과는 부갑상선 선종이 73명(83.9\%)으로 가 장 많았으며 부갑상선 증식증이 8명(9.2\%), 부갑상선 암이 4명

Table 1. Clinicopathologic characteristics of patients with primary hyperparathyroidism

\begin{tabular}{lc}
\hline \multicolumn{1}{c}{ Variables } & $\mathrm{n}(\%)$ \\
\hline Sex & $24(27.6)$ \\
Male & $63(72.4)$ \\
Female & $58.7 \pm 15.6$ \\
Ages (year) & \\
Symptoms & $61(70.1)$ \\
Asymptomatic & $12(13.8)$ \\
Bone pain & $5(5.7)$ \\
Urinary tract stone & $4(4.6)$ \\
Fatigue/general weakness & $2(2.3)$ \\
Neck mass & $2(2.3)$ \\
Gastrointestinal symptoms & $1(1.1)$ \\
Muscle cramp & \\
Preoperative serum & $11.11 \pm 1.49$ \\
Ca (mg/dL) & $220.79 \pm 270.64$ \\
iPTH (pg/mL) & \\
Postoperative serum (at 1 week) & $8.90 \pm 0.90$ \\
Ca (mg/dL) & $27.60 \pm 27.59$ \\
iPTH (pg/mL) & \\
Postoperative serum (at 6 months) & $9.27 \pm 0.65$ \\
Ca (mg/dL) & $52.18 \pm 38.22$ \\
iPTH (pg/mL) & \\
Pathology & $73(83.9)$ \\
Adenoma & $8(9.2)$ \\
Hyperplasia & \\
Carcinoma & \\
Parathyroid cyst & \\
\hline
\end{tabular}

iPHT: intact parathyroid hormone
(4.6\%), 부갑상선 낭종이 2명(2.3\%)이었다(Table 1).

\section{병변의 위치 확인을 위한 영상검사}

부갑상선 병변의 위치를 우상, 우하, 좌상, 좌하 4가지로 나 누고, 영상검사에서 표시되는 병변의 위치와 실제 병변의 위 치가 일치하는지를 조사하였다. 경부 초음파검사를 시행한 87예 중 73예에서, 경부 전산화단층촬영 52예 중 47예에서, 부갑상선 스캔 80예 중 71예에서 병변의 위치가 확인되었다. 경부 초음파와 부갑상선 스캔을 함께 시행한 80예, 경부 초 음파와 경부 전산화단층촬영을 시행한 52예, 세가지 검사를 모두 시행한 48예에서는 각각 78예, 47예, 45예에서 병변의 위치가 확인되어 검사의 정확도는 각각 $98 \%, 90 \%, 94 \%$ 였다 (Table 2).

\section{수술 방법 및 합병증}

수술 방법은 양측 경부탐색법이 20예(23.0\%), 일측 경부탐 색법이 17예(19.5\%), direct focused parathyroidectomy가 50예(57.5\%)였다(Table 3). 부갑상선 선종의 경우 direct focused parathyroidectomy가 48예, 일측 경부탐색법이 13예, 양측 경부탐색법이 12 예에서 시행되었으며, 부갑상선 증식증 은 양측 경부탐색법이 7예, 일측 경부탐색법이 1예에서 시행 되었고, 부갑상선암은 일측 경부탐색법 3예, 양측 경부탐색법 1 예였다(Table 3). 87예 중 11예에서는 갑상선 병변으로 갑상선 절제술이 같이 시행되었으며, 악성이 2예, 양성이 9예였으며, 함께 시행한 갑상선 절제술로는 전절제술이 3예, 엽절제술이 4예, 갑상선 부분절제술이 3예였다. 갑상선 절제술을 같이 시

Table 2. Detection rates of localization test

\begin{tabular}{lcc}
\hline & $\begin{array}{c}\text { No. of patients detected/ } \\
\text { no. of patients examined }\end{array}$ & Accuracy (\%) \\
\hline US & $73 / 87$ & 84 \\
Scan & $71 / 80$ & 89 \\
CT & $47 / 52$ & 90 \\
US+scan & $78 / 80$ & 98 \\
US+CT & $47 / 52$ & 90 \\
US+scan+CT & $45 / 48$ & 94
\end{tabular}

No: number, US: ultrasonography, Scan: ${ }^{99 m} \mathrm{Tc}$-sestamini scan, CT: computerized tomography

Table 3. Surgical methods according to pathology of hyperparathyroidism

\begin{tabular}{lcccc}
\hline & $\begin{array}{c}\text { Bilateral } \\
\text { exploration } \\
(\mathrm{n}=20)\end{array}$ & $\begin{array}{c}\text { Unilateral } \\
\text { exploration } \\
(\mathrm{n}=17)\end{array}$ & $\begin{array}{c}\text { Direct focused } \\
\text { approach } \\
(\mathrm{n}=50)\end{array}$ & Total \\
\hline Adenoma & 12 & 13 & 48 & 73 \\
Hyperplasia & 7 & 1 & 0 & 8 \\
Carcinoma & 1 & 3 & 0 & 4 \\
Cyst & 0 & 0 & 2 & 2 \\
\hline
\end{tabular}


행한 11 예 중 6 예는 양측 경부탐색법, 5 예는 일측 경부탐색법 이 시행되였다.

갑상선 절제술을 같이 시행한 11 예를 제외하고 부갑상선 선종군에서 분석한 평균 수술 시간은 양측 경부탐색법, 일측 경부탐색법, direct focused parathyroidectomy군에서 각각 $97.8 \pm 35.7$ 분, $81.0 \pm 15.8$ 분, $69.4 \pm 7.5$ 분로 양측 경부탐색법군 의 수술 시간은 다른 두 군의 수술 시간보다 통계적으로 유 의하게 길었다 $(p=0.017)$. 술후 합병증으로는 양측 경부탐색 법군에서 술후 혈종 1 예, 일시적 성대마비 1 예, 일시적 저칼슘 혈증 1예, 골기아증후군(hungry bone syndrome) 1 예가 있었 으며 성대마비는 갑상선 절제술을 같이 시행한 예에서 발생 하였다. Direct focused parathyroidectomy군에서도 일시적 성대마비가 1예에서 발생하였다. 수술 후 재발은 총 87예 중 2예(2.3\%)로, 양측 경부탐색술군과 direct focused parathyroidectomy군에서 각각 1 예씩 발생하였다. 재발율은 양측 경 부 탐색술군이 $5 \%$, 일측 경부 탐색술군이 $0 \%$, direct focused parathyroidectomy군이 $2 \%$ 였으며, 술식에 따른 재발율의 유 의한 차이는 없었다 $(p=0.586)$ (Table 4).

\section{고 찰}

원발성 부갑상선 기능 항진증은 부갑상선 선종에 의한 경 우가 대부분이며 근본적인 치료는 수술적 절제이다. 하지만 부갑상선 절제술의 적응증은 아직 명확히 확립되지 않았다. 증상이 있는 모든 원발성 부갑상선 기능 항진증은 수술의 적 응증이 되지만, 증상이 없는 환자의 수술 여부는 아직 논란 이 있다. 증상이 없는 환자라도 1) 나이가 50세 미만인 경우, 2) 혈중 칼슘농도가 정상 상한치보다 $1 \mathrm{mg} / \mathrm{dL}$ 이상 높은 경 우, 3) $\mathrm{Cr}$ clearance가 $60 \mathrm{cc} / \mathrm{min}$ 미만 또는 urine $\mathrm{Ca}$ 이 400 $\mathrm{mg} / 24 \mathrm{hr}$ 이상이어서 요석 발생의 위험이 증가될 수 있는 경 우, 4) 골다공증이 심한 경우(T-score<-2.5)인 경우는 수술적 치료의 적응증이 된다. ${ }^{6)}$ 또한, 부갑상선 절제술은 성공률이
높고 위험성은 낮기 때문에 수술 적응증에 해당하지 않는 환 자에서의 추적 관찰은 시간 및 비용적으로 유용하지 않다는 것이 요즈음의 지배적인 의견이다. 최근에는 무증상 환자의 약 50\%에서 5년 내지 7년 내에 합병증이 발현된다는 보고가 있어 적응증에 해당하지 않는 경증의 환자라 하더라도 초기 에 수술을 하는 경우가 증가하고 있다. ${ }^{7)}$

원발성 부갑상선 기능 항진증의 수술 방법으로 양측 경부 탐색술은 수십 년간 표준 술식으로 시행되고 있다. 양측 경부 탐색술의 치료 성공률은 95\% 이상으로 매우 높으며, 4 개의 부갑상선을 모두 확인하여 크기가 커진 또는 기능이 항진된 것으로 추정되는 부갑상선을 절제하는 방법이다. ${ }^{8}$ 과거에는 양측 경부 탐색술에서 모든 부갑상선의 조직검사를 통해 모 든 부갑상선을 확인하였다. 하지만 조직검사로 인해 혈류 장 애가 발생할 수 있는 위험성 때문에 현재는 정상 부갑상선의 조직검사를 지양하는 편이다. 양측 경부 탐색술은 모든 부갑 상선의 상태를 확인할 수 있어 수술 실패율이 낮으며 부갑상 선 증식증과 같은 여러 부갑상선을 침범하는 병변에 유용하 다. 하지만 수술 범위가 넓어 수술 이환율이 높고, 수술 시간 및 술후 회복 기간이 길다는 단점이 있다. 본 연구에서도 양 측 경부 탐색술의 수술 시간은 일측 경부탐색술이나 direct focused parathyroidectomy에 비하여 유의하게 길었다. Nor$\operatorname{man}$ 등도 최소 침습수술이 양측 경부탐색술보다 수술 시간, 절개 길이, 술후 회복 기간 등이 모두 적었다 보고하였다. ${ }^{9}$

원발성 부갑상선 기능 항진증의 80 85\%는 단발성 병변이 며 최근에는 영상 검사의 발달로 술전 병변의 위치 확인이 가 능해 졌으며 술중 부갑상선 호르몬 측정이 가능하고, 방사선 유도 수술법 등이 도입됨에 따라 일측 경부탐색법 또는 최소 침습 수술법이 도입되었다. 일측 경부탐색법은 병변과 같은 쪽에 있는 2 개의 부갑상선을 탐색하여 병변이 있는 부갑상선 을 절제하고 다른 부갑상선을 조직 검사하여 병변이 없음을 확인하는 수술법이다. ${ }^{10)}$ Direct focused parathyroidectomy 는 수술 전 영상검사에서 병변으로 확인된 부갑상선만을 정

Table 4. Surgical outcome by surgical methods

\begin{tabular}{|c|c|c|c|c|}
\hline & $\begin{array}{l}\text { Bilateral exploration } \\
\qquad(\mathrm{n}=20)\end{array}$ & $\begin{array}{l}\text { Unilateral exploration } \\
\qquad(n=17)\end{array}$ & $\begin{array}{l}\text { Direct focused approach } \\
\qquad(n=50)\end{array}$ & $p$-value* \\
\hline Operative time $(\mathrm{min})$ & $97.8 \pm 35.7$ & $81.0 \pm 15.8$ & $69.4 \pm 7.5$ & 0.017 \\
\hline \multicolumn{5}{|l|}{ Complications (\%) } \\
\hline Hematoma & $1(5.0)$ & 0 & 0 & 0.184 \\
\hline Vocal cord palsy & $1(5.0)$ & 0 & $1(2.0)$ & 0.586 \\
\hline Infection & 0 & 0 & 0 & \\
\hline Hypocalcemia & $1(5.0)$ & 0 & 0 & 0.184 \\
\hline Hungry bone syndrome & $1(5.0)$ & 0 & 0 & 0.184 \\
\hline Recurrence (\%) & $1(5.0)$ & 0 & $1(2.0)$ & 0.586 \\
\hline
\end{tabular}

Operation time was compared in cases with adenoma. *for comparison of three independent groups, Kruskall Wallis test was used for operation time and chi-square test was used for complication, recurrence and success rate 
확히 찾아 절제하는 방법이다. 일측 경부탐색법이나 최소 침 습 수술법은 기존의 양측 탐색에 비하여 수술 반흔이 적고 수술 시간을 단축시킬 수 있으며 술후 회복 기간이 짧고, 치 료 성공률 또한 양측 경부탐색법과 유의한 차이가 없다. ${ }^{11,12)}$ 하지만, 술전 영상 검사에서 병변의 위치를 찾지 못하는 경 우는 수술 성공률이 떨어지며, 확인하지 않은 나머지 부갑상 선들이 정상임을 확인할 수 없는 단점이 있어 모든 부갑상선 을 확인해야 하는 부갑상선 증식증에는 적합하지 않은 술식 이다. ${ }^{5,13)}$

본 연구에서 재발은 87예 중 2예에서 발생하였는데, 양측 경부탐색술과 direct focused parathyroidectomy 후에 각각 1 예씩 발생하여 3가지 술식 간의 재발율의 유의한 차이는 없 었다. 본 연구의 결과같이 원발성 부갑상선 기능 항진증의 수 술에서 direct focused parathyroidectomy는 합병증과 재발 율에 차이가 없고 수술의 이환율을 줄일 수 있는 좋은 방법 이라 생각되는데, 수술의 성공을 위해서는 술전 정확히 병변 의 위치를 파악하는 것이 반드시 필요하다. ${ }^{14,15}$ 본 연구에서는 수술 전 병변 위치를 파악하기 위하여 경부 초음파검사, 경부 전산화단층촬영술 및 부갑상선 스캔을 사용하였으며, 경부 초음파의 정확도는 $84 \%$, 부갑상선 스캔은 $89 \%$ 였으며 두 검 사를 함께 시행한 경우는 $98 \%$ 였다.

원발성 부갑상선 기능항진증의 수술에서 흔한 실패 원인은 숨어있는 병변을 찾지 못하는 경우이며 그 외에도 술중 부갑 상선 호르몬 검사(intraoperative PTH assay) 결과의 오류, 동결절편 검사 결과의 오류, 불충분한 병변의 절제 등이 있 다. ${ }^{16,17)}$ 따라서 술전 병변의 위치를 알기 위한 검사를 시행하 였다 하더라도 술중 병변이 존재할 수 있는 모든 위치를 탐 색하는 것이 중요하며, 부갑상선 선종이 갑상선 내 위치하거 나 흥선 또는 경동맥초 주위, 식도 뒤편에 위치할 수 있다는 것을 염두에 두어야 한다. ${ }^{14)}$ 부갑상선 증식증 등의 다발성 병 변이 있을 때도 병변의 불충분한 제거로 수술이 실패할 수 있 으며, 시간차를 두고 다발성으로 다른 부갑상선이 증식하는 다발성 병변도 실패의 원인이 된다. ${ }^{16,17)}$
본 연구에서 재발한 2예 중 1예는 direct focused parathyroidectomy로 수술한 부갑상선 선종 환자로 첫 수술 시에 식도 뒤로 위치한 부갑상선종을 찾지 못하고 다른 정상 부갑 상선을 절제하여 수술에 실패하였으며, 수술 후 혈중 칼슘 및 $\mathrm{iPTH}$ 농도가 지속적으로 증가하여 2년 후에 재수술을 시행하였다. 재수술 시 일측 경부탐색법을 시행하였으며 식 도 뒤로 위치한 우상 부갑상선에 발생한 부갑상선 선종을 확 인하고 제거하였으며 이후 추가 재발은 없었다(Fig. 2). 재발 한 다른 1 예는 부갑상선 증식증으로 양측 경부탐색법을 통 하여 증식된 우측 2 개의 부갑상선을 절제하였으며, 수술 다 음 날 혈중 칼슘농도와 부갑상선 호르몬 수치가 여전히 높아 수술 1주일 후 재수술을 시행하였으며, 조금 커져있는 좌측 하부의 부갑상선을 추가로 제거하였으며, 이후 추가 재발은 없었다.

Direct focused parathyroidectomy의 단점은 다발성 선종 이나 부갑상선 증식증이 있는 경우 다른 병변을 놓쳐 수술에 실패할 수 있는 것인데, 수술로 모든 부갑상선 병변이 제거 되었는지를 수술 종료 전에 확인하기 위해 술중 부갑상선 호 르몬 검사가 시행된다. 이는 단발성 부갑상선 선종의 절제 후 다른 부갑상선 병변이 없는지 확인할 수 있어 부갑상선 절제 술의 수술 성공율을 높일 수 있는 장점이 있다. 하지만, 술중 부갑상선 호르몬 검사에서 약 $10 \%$ 의 위음성이 있으며, $\mathrm{Mi}-$ ura 등 ${ }^{18}$ 은 단발성 부갑상선 병변에서 술전 경부 초음파 및 부갑상선 스캔검사로 $95 \%$ 의 수술 성공률을 얻었으며, 여기 에 술중 부갑상선 호르몬 검사를 추가로 하였을 경우의 수술 성공률은 $97 \%$ 로 큰 차이가 없어 술중 부갑상선 호르몬 검사 의 비용 효율을 고려하였을 때 큰 이득이 없다 하였다. 또한 다발성 부갑상선 병변의 경우 술중 부갑상선 호르몬 검사를 시행하여도 수술 성공률이 58\%로 높지 않아, 다발성 병변에 서는 술중 부갑상선 호르몬 검사가 유용하지 않다. ${ }^{18,19)}$ 이러 한 단점을 고려하여 저자들은 술중 부갑상선 호르몬 검사를 통상적으로 시행하지 않으며, 본 연구에서도 시행된 예가 없 었다.
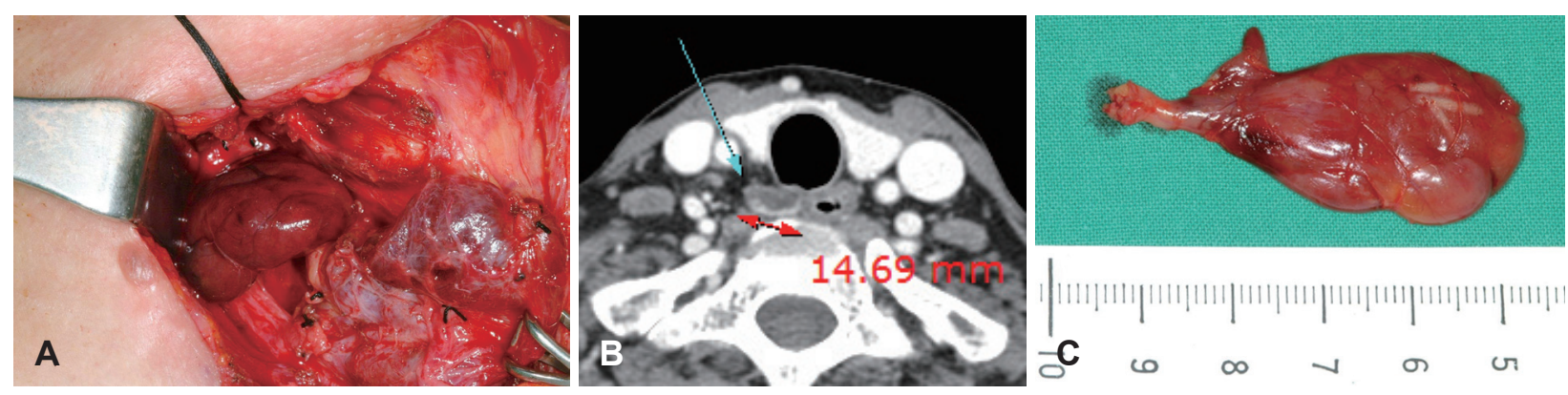

Fig. 2. Reoperation for parathyroid adenoma. On the CT image, an about $2 \mathrm{~cm}$ sized parathyroid lesion is noted at the retroesophageal area (A). Parathyroid adenoma of the right upper parathyroid gland located behind the esophagus is identified and removed (B). Surgical specimen $(C)$. 
부갑상선 절제술의 합병증으로는 수술 부위 혈종 및 감염, 반회후두신경의 손상, 골기아 증후군, 재발 등이 있다. ${ }^{20)}$ 본 연구에서는 성대마비가 2예에서 발생하였는데 술후 2 개월 이 내에 모두 정상으로 회복되었다. 술후 저칼슘혈증은 보통 경 미하며 4일 이내 회복되는 경우가 대부분이나 술전 심한 부 갑상선 기능 항진증 환자의 경우 그 정도가 심하고(혈중 칼 슘 농도 $<2.1 \mathrm{mmol} / \mathrm{L})$ 오래 지속되며 골기아 증후군을 유발 할 수 있다. 골기아 증후군은 혈중 높은 부갑상선 호르몬에 의해 골흡수가 만성적으로 증가하여 술전 골질환이 발생한 환자에서 흔하게 발생한다. 이러한 환자에서 부갑상선 절제 술후 혈중 부갑상선 호르몬이 갑작스럽게 낮아지게 되면 칼 슘, 인산염 및 마그네슘의 골 흡수가 현저히 증가하게 되고 이는 혈중 칼슘, 인산, 마그네슘 농도의 저하를 유발하게 된 다. 치료는 전해질 불균형에 대한 대증적 치료이며 심한 경우 투석을 시행한다. ${ }^{20)}$ 본 연구에서는 1 예에서 일시적 저칼슘혈 증이 발생하였고, 다른 1 예에서는 골기아 증후군에 의한 저칼 슘혈증이 발생하였으나 보존적 치료로 술후 약 1달 경에 정 상으로 회복되었다.

본 연구에는 필연적인 단점과 제한점이 있다. 첫째, 술식에 따른 술후 결과를 정확히 비교하기 위해서는 단일 질환군에 서 무작위로 시행된 수술을 비교하여야 하는데, 본 연구에는 선종, 증식증, 암 등 여러 병변이 같이 포함되어 있고 수술도 무작위로 시행되지 않아 분석에 제한 점이 있다, 둘째, 본 연 구는 또한 갑상선 수술을 같이 시행한 경우를 포함하고 있어 부갑상선 수술의 결과 분석에서 교란 변수로 작용할 수 있다 는 단점이 있다.

결론적으로, 원발성 부갑상선 기능 항진증에 대한 수술의 성공율은 매우 높으며, 술전 영상검사로 병변의 위치를 알 수 있으면 direct focused parathyroidectomy가 좋은 수술 방 법이라 생각된다. 하지만 부갑상선 증식증에서는 양측 경부 탐색법이 유용한 술식이라 사료된다.

\section{Acknowledgments}

None.

\section{Author Contribution}

Conceptualization: Kyung Tae. Data curation: Hee Jeong Kang. Formal analysis: Hee Jeong Kang. Methodology: Hee Jeong Kang, Hee Ryung Kim, Ha Na Lee. Project administration: Kyung Tae. Resources: Chang Myeon Song, Yong Bae Ji, Kyung Tae. Supervision: Kyung Tae. Validation: Kyung Tae, Chang Myeon Song, Yong Bae Ji. Writing — original draft: Hee Jeong Kang. Writing — review \& editing: Hee Ryung Kim, Ha Na Lee, Chang Myeon Song, Yong Bae Ji, Kyung Tae.

\section{ORCID}

Kyung Tae

https://orcid.org/0000-0002-0382-2072

\section{REFERENCES}

1) Pasieka JL, Parsons LL. Prospective surgical outcome study of relief of symptoms following surgery in patients with primary hyperparathyroidism. World J Surg 1998;22(6):513-8; discussion 518-9.

2) Chan AK, Duh QY, Katz MH, Siperstein AE, Clark OH. Clinical manifestations of primary hyperparathyroidism before and after parathyroidectomy. A case-control study. Ann Surg 1995;222(3): 402-14.

3) DeLellis RA. Surgical pathology of the parathyroid glands. In: Randolph GW, editor. Surgery of the thyroid and parathyroid glands. Philadelphia: Elsevier Saunders;2013. p.673-80.

4) Marcocci C, Cetani F, Rubin MR, Silverberg SJ, Pinchera A, Bilezikian JP. Parathyroid carcinoma. J Bone Miner Res 2008; 23(12):1869-80.

5) Chang HS, Yoon JH, Chung WY, Park CS. Minimally invasive focused parathyroidectomy (MIFP). Ann Surg Treat Res 2004; 66(6):467-71.

6) Farndon JR. Postoperative complications of parathyroidectomy. In: Holzheimer RG, Mannick JA, editors. Surgical Treatment: EvidenceBased and Problem-Oriented. Munich: Zuckschwerdt;2001.

7) Silverberg SJ, Shane E, Jacobs TP, Siris E, Bilezikian JP. A 10-year prospective study of primary hyperparathyroidism with or without parathyroid surgery. N Engl J Med 1999;341(17):1249-55.

8) Chen H. Surgery for primary hyperparathyroidism: What is the best approach? Ann Surg 2002;236(5):552-3.

9) Norman J, Chheda H, Farrell C. Minimally invasive parathyroidectomy for primary hyperparathyroidism: Decreasing operative time and potential complications while improving cosmetic results. Am Surg 1998;64(5):391-5; discussion 395-6.

10) Burkey SH, Snyder WH 3rd, Nwariaku F, Watumull L, Mathews D. Directed parathyroidectomy: Feasibility and performance in 100 consecutive patients with primary hyperparathyroidism. Arch Surg 2003;138(6):604-9.

11) Starker LF, Fonseca AL, Carling T, Udelsman R. Minimally invasive parathyroidectomy. Int J Endocrinol 2011;2011:206502.

12) Grant CS, Thompson G, Farley D, van Heerden J. Primary hyperparathyroidism surgical management since the introduction of minimally invasive parathyroidectomy: Mayo Clinic experience. Arch Surg 2005;140(5):472-9.

13) Udelsman R, Lin $Z$, Donovan P. The superiority of minimally invasive parathyroidectomy based on 1650 consecutive patients with primary hyperparathyroidism. Ann Surg 2011;253(3):585-91.

14) Tae K, Lee YS, Kim KR, Lee HS, Park DW, Park YS, et al. Radiologic diagnosis and surgical treatment of primary hyperparathyroidism. Korean J Otolaryngol 2006;49(7):733-9.

15) Sung ES, Ji YB, Choi YY, Kim JY, Park JS, Lee YJ, et al. Comparative study of preoperative imaging detection and localization test for hyperparathyroidism. Korean J Otorhinolaryngol-Head Neck Surg 2012;55(9):565-70.

16) Lew JI, Rivera M, Irvin GL 3rd, Solorzano CC. Operative failure in the era of focused parathyroidectomy: A contemporary series of 845 patients. Arch Surg 2010;145(7):628-33.

17) Agarwal A, Pradhan R. Failed parathyroidectomy: The road ahead. Indian J Endocrinol Metab 2012;16(Suppl 2):S221-3.

18) Miura D, Wada N, Arici C, Morita E, Duh QY, Clark OH. Does intraoperative quick parathyroid hormone assay improve the results of parathyroidectomy? World J Surg 2002;26(8):926-30.

19) Chen H, Pruhs Z, Starling JR, Mack E. Intraoperative parathyroid hormone testing improves cure rates in patients undergoing minimally invasive parathyroidectomy. Surgery 2005;138(4):583-90.

20) Witteveen JE, van Thiel S, Romijn JA, Hamdy NA. Hungry bone syndrome: Still a challenge in the post-operative management of primary hyperparathyroidism: A systematic review of the literature. Eur J Endocrinol 2013;168(3):R45-53. 